\title{
Transfer of Pygmaeotinea crisostomella Amsel, 1957 from Tineidae to Psychidae and its taxonomic status (Lepidoptera)
}

\author{
Thomas SobCZYK ${ }^{1}$
}

1 Diesterwegstraße 28,D-02977 Hoyerswerda, Germany,email: ThomasSobczyk@aol.com

http://zoobank.org/9E0B96CC-B486-4B01-849D-D560DF146DFE

Received 14 April 2015; accepted 13 July 2015; published: 7 August 2015

Subject Editor: Jadranka Rota.

\begin{abstract}
Pygmaeotinea Amsel, 1957, syn. n. is transferred from Tineidae to Psychidae and regarded as congeneric with Eumasia Chrétien, 1904. The type species of Pygmaeotinea is combined with Eumasia as Eumasia crisostomella Amsel, 1957, comb. n. Adult male and female of this species are redescribed and illustrated for the first time. Eumasia crisostomella Amsel, 1957 is only known from the type locality in Portugal at Singeverga and one of three Eumasia species from Iberian Peninsula.

Zusammenfassung. Pygmaeotinea Amsel, 1957, syn. n. wird von den Tineidae zu den Psychidae transferriert und ist congenerisch mit Eumasia Chrétien, 1904. Die Typusart von Pygmaeotinea wird mit Eumasia als Eumasia crisostomella Amsel, 1957, comb. n. kombiniert. Adulte Männchen und Weibchen dieser Art werden erstmals abgebildet und die Beschreibung durch weitere Merkmale ergänzt. Eumasia crisostomella Amsel, 1957 ist nur von der Typenlokalität bekannt und eine von drei Eumasia-Arten der Iberischen Halbinsel.
\end{abstract}

\section{Introduction}

The monotypic Pygmaeotinea Amsel, 1957 was described within Tineidae. Its type-species, P. crisostomella Amsel, 1957 is only known from the type specimens and no further specimens have been reported thus far.

Amsel (1957) noted that the relationship of Pygmaeotinea crisostomella to other Tineidae is unknown. Karsholt and Razowski (1996) placed the genera Eumasia and Pygmaeotinea together with Apterona Millière, 1857 within Apteronini (Psychidae, Oiketicinae). Sauter and Hättenschwiler (1999) argued that this placement was done by the editors and does not reflect the opinion of the authors. They do not consider the first genus as belonging to Apteronini. Unfortunately, the original description does not allow us to judge the systematic placement of Pygmaeotinea, except that the information available suggests that it does not belong to Psychidae (Sauter and Hättenschwiler 1999).

Recently, Pygmaeotinea was re-transferred to Tineidae by Sobczyk (2011), but still provisionally. Even more recently, Gaedike (Bonn) found the type-series at the Staatliches Museum für Naturkunde Karlsruhe (SMNK). As an expert of Tineidae, after having examined the specimens, he came to the conclusion that they do not belong to Tineidae. Subsequently, he kindly arranged the loan of the type specimens to me. 


\section{Systematic part}

Eumasia crisostomella Amsel, 1957, comb. n.

Figs 1-6

Examined material. Holotype $\widehat{\jmath}$ "vi [1]950 / Singeverga" back cover (handwritten Amsel) "Portugal / coll. Monteiro", "GU 3199”, red label "Pygmaetinea crisostomella”, "coll. SMNK”, genital slide with same information and additional "Holotypus"; Paratype 1 q "Singeverga / vi.1953" back cover (handwritten Amsel) "Portugal / coll. Monteiro", genital preparation 3198, red label "Allotypus +, leg. H. Amsel”, “coll. SMNK”.

\section{Citation of original description by Amsel.}

(Pygmaeotinea)

Fühler des $\widehat{\jmath}$ kurz bewimpert, bis etwa 1/2 Costa reichend. Kopfhaare abstehend. Vflg.-Geäder: Zelle offen, nur 3 Radialadern: r2+r3 und r3+r4 zu je einer Ader zusammengefallen; mit m1 und r4+r5 gestielt; m2 fehlend; ax ohne Wurzelschlinge. Hflg.-Geäder: rr und m1 gestielt, die Spitze umgreifend, m2 fehlend. Axillaradern stark reduziert. Genitalapparat des $\widehat{\jmath}$ : Uncus abgerundet, Gnathos fehlend, Vinculum (Saccus) zugespitzt, Valven in einen basalen und einen terminalen Teil gegliedert, ohne sonstige Strukturen.

(crisostomella)

Spw. 7 mm. Kopfhaare gelblich, Palpen bräunlich. Fühler des ô bis 1/2 Costa reichend, sehr kurz bewimpert, fast pubscent. Zwischen oberen Außenrand und der Fühlerwurzel ein großer quecksilberartiger Fleck. Vfgl. Gelblich. Ein großer bräunlicher Fleck am Innenrand bei 1/2, weitere Flecke im apikalen Flügelteil. Die Art ist durch den großen, fast viereckigen Fleck am Innenrand bei $1 / 2$ gut charakterisiert. An der Costa stehen einige bräunliche Schuppen, im äußeren Drittel der Flügel häufen sich diese zu Flecken. Fransen graubraun. Hflg. Nur wenig schmaler als die Vflg. Fransen etwas länger als der Flügel breit ist. Beine ungeringelt. Genitalapparat des $\hat{\jmath}$ : Uncus abgerundet, Gnathos fehlend. Vinculum ziemlich lang, zugespitzt. Valven aus zwei Teilen bestehend, einen äußeren, nicht strukturierten und einen inneren, der deutlich gegenüber dem Außenteil abgesetzt ist. Aedoeagus leicht gebogen, ziemlich lang, ohne Cornuti. Genitalpräparat 3199 (...) Einige Stücke wurden aus abgeflachten Säcken gezüchtet, die $7 \mathrm{~mm}$ lang mit Sandkörnchen besetzt sind.

Redescription crisostomella. Forewing length (with fringes) 3.5-4 mm, wingspan 7-8 $\mathrm{mm}$. Labial palpi tripartite, median segment of double width and equal length as distal segment. Both segments covered with brown, ventrally directed hair-like scales. Antennal segments round, covered with short setae, dorsally with a semi-circular fan-like arrangement of broad, dark brown scales. The angle of this fan is $30-40^{\circ}$ (see description of measurement by Hättenschwiler 1998). Forelegs with bristle brush (without epiphysis). Forewing scales long-oval, rounded distally, usually four- to six-pointed. Forewing ground colour yellowish, with a distinct dark brown spot at $1 / 2$ of posterior margin and partly the anterior margin with some very narrow dark brown spots; distal third significantly spotted and converging partially to transverse lines. Fringe gray, hair-like, bi- or tricuspid. Hindwings uniformly dark gray. Male genitalia (genital preparation no. 3199 by Amsel): Total length $0.5 \mathrm{~mm}$, very weakly sclerotized (perhaps an artifact due to excessive maceration). In ventral view, almost three times as long as wide. Valva extending beyond posterior margin of tegumen, weakly sclerotized distally with fine setae. Phallus $0.4 \mathrm{~mm}$ long, tubular, almost straight. 


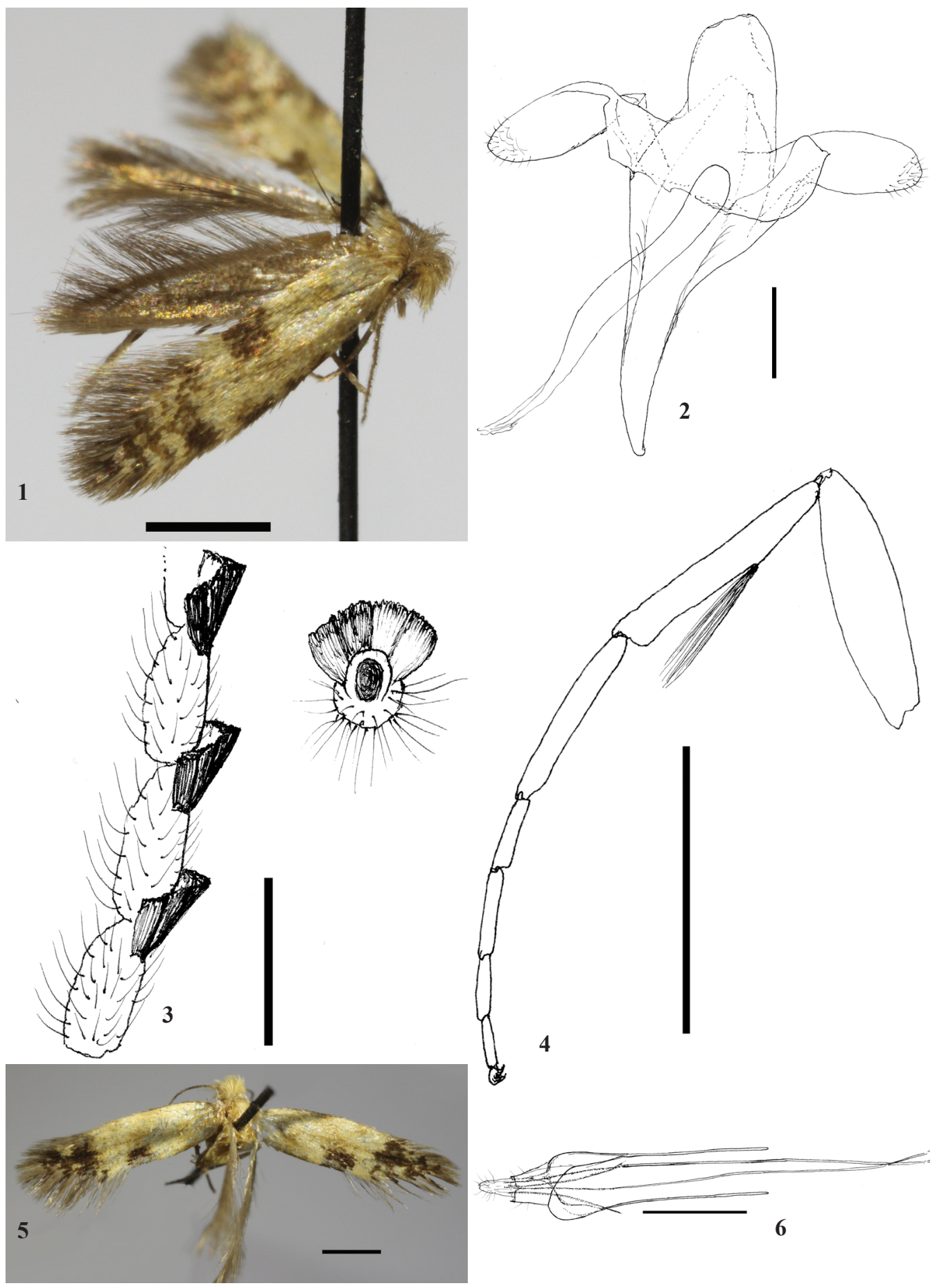

Figures 1-6. Eumasia crisostomella Amsel, 1957. 1. $\widehat{\jmath}$ Holotype, Portugal, Singeverga, vi. [1]950. 2. Holotype genital preparation 3199. 3. Detail antennae. 4. Foreleg. 5. $q$ Paratype $q$ same data, but vi.1953. 6. $q$ Paratype genital preparation 3198. Scale bar: $1 \mathrm{~mm}(\mathbf{1}, \mathbf{5}), 0.1 \mathrm{~mm}(\mathbf{2}, \mathbf{3}), 0.5 \mathrm{~mm}(\mathbf{4}, \mathbf{6})$. 
Female (differences to males). Antenna filiform, wingspan $8 \mathrm{~mm}$. Wing pattern as in the male, but missing dark spots at the anterior margin of basal 2/3 of the forewings. Abdominal segment eight with dense, wavy hairs. Female genitalia (genital preparation no. 3198 by Amsel): $2.0 \mathrm{~mm}$ total length. Oviscapt with fine setae distally, supported by three pairs of apophyses. Posterior apophyses with a length of $1.9 \mathrm{~mm}$, almost as long as the entire genitalia, anterior apophyses $0.85 \mathrm{~mm}$ long, forked distally, distal edge of antevaginal plate concave, covered with fine, distally directed spines. Ovipositor also with a third pair of 0.5-mm-long apophyses.

Diagnosis. E. crisostomella Amsel, 1957, comb. n. differs from E. parietariella (Heydenreich, 1851) from Central and South Europe and Eumasia brunella Hättenschwiler, 1998 from the Iberian Peninsula by the forewing pattern. Forewings of the latter two species are also covered with dark spots basally, but the dark spots of E. crisostomella are concentrated on distal third. On the basal $2 / 3$ there are two or three small partial dark spots on the anterior margin. Most conspicuous is a large, almost square dark spot in the middle of the posterior margin. Hindwings of E. parietariella are light cream, of E. brunella brown and of E. crisostomella grey.

Remarks. The original description of Pygmaeotinea neither contains information about a differentiation from other genera nor why the description of a new genus was considered necessary. The venation (figure 5, Amsel 1957) and antennal and genital structures are clearly consistent with typical structures of Eumasia. A diagnosis for the genus is given by Hättenschwiler (1998). Particularly noteworthy is the scalation of the male antennae with a dorsally semi-circular fanlike arrangement of broad scales. Each antennal segment has a dorsal compartment of broader scales. Thus, Pygmaeotinea Amsel, 1957, syn. n. is identical to Eumasia Chrétien, 1904 and is synonymized here with it and its type species transferred to Eumasia, as Eumasia crisostomella Amsel, 1957, comb. n.

The label data do not completely match with information provided in the original description. Holotype $\widehat{\jmath}$ denotes VI. [1]950 as date. There was no label on the pinned specimen that indicated it as the holotype. That information was only present on the genital slide belonging to this specimen and the slide number 3199 is present on both, the genitalia slide and on the pinned holotype specimen.

In the description the date for the female (allotype) is listed as vi.1950; however, the specimen label reads 'vi.1953'.

\section{Acknowledgements}

I thank Reinhard Gaedike (Bonn), who inspired the study, and Peter Hättenschwiler, who provided important information. I thank Robert Trusch and Michael Falkenberg (both State Museum of Natural History, Karlsruhe, Germany) for the loan of the type material of E. crisostomella. Last but not least, I thank Matthias Nuss (Senckenberg Museum of Zoology Dresden) for comments on the manuscript.

\section{References}

Amsel HG (1957) Neue Microtineiden aus Portugal (Lepidoptera, Tineidae). Beiträge zur naturkundlichen Forschung in Südwestdeutschland 16: 30-33.

Hättenschwiler P (1998) Neue Eumasia Arten aus Mittelspanien und den Malediven und einige Ergänzungen zur Kenntnis der Gattung Eumasia (Psychidae). Nota lepidopterologica 21(4): 264-282. 
Sauter W, Hättenschwiler P (1991) Zum System der palaearktischen Psychiden (Lep., Psychidae) 1. Teil: Liste der palaearktischen Arten. Nota lepidopterologica 14 (1): 69-89.

Sauter W, Hättenschwiler P (1996) Psychidae. In: Karsholt O, Nielsen ES. The Lepidoptera of Europe. A distributional Checklist. Apollo Books, Stenstrup, 39-46.

Sauter W, Hättenschwiler P (1999) Zum System der palaearktischen Psychiden (Lep., Psychidae). 2. Teil: Bestimmungsschlüssel für die Gattungen. Nota lepidopterologica 22(4): 262-195.

Sobczyk T (2011) Psychidae. World Catalogue of Insects 10. Apollo Books Stenstrup, 467 pp. 